\title{
Planktonic community production and respiration and the impact of bacteria on carbon cycling in the photic zone of Lake Kinneret
}

\author{
T. Berman*, A. Parparov, Y. Z. Yacobi \\ Yigal Alon Kinneret Limnological Laboratory, Israel Oceanographic and Limnological Research, PO Box 447 , \\ Migdal 14 950, Israel
}

\begin{abstract}
The following parameters were determined in the photic zone of Lake Kinneret from January 2001 through December 2002: primary production (PP), community respiration (CR), bacterial biomass production (BBP), bacterial numbers $(\mathrm{BN})$ and biological oxygen demand $\left(\mathrm{BOD}_{5}\right)$. Average values over the $2 \mathrm{yr}$ period for these parameters in the photic zone (0 to $15 \mathrm{~m})$ were $\mathrm{PP}$, $1539 \mathrm{mg} \mathrm{C} \mathrm{m}^{-2} \mathrm{~d}^{-1}$; $\mathrm{CR}, 1653 \mathrm{mg} \mathrm{C} \mathrm{m}^{-2} \mathrm{~d}^{-1}$; $\mathrm{BBP}, 887 \mathrm{mg} \mathrm{C} \mathrm{m}^{-2} \mathrm{~d}^{-1}$; $\mathrm{BN}, 4.6 \times 10^{6} \mathrm{cells} \mathrm{ml}^{-1}$; and BOD , $6366 \mathrm{mg} \mathrm{C} \mathrm{m}^{-2}$. We used these data together with literature-based assumptions about the ratio of net to gross primary production, bacterial and zooplankton respiration to estimate bacterial growth efficiencies (BGE) ranging from 44 to $64 \%$. Bacterial specific growth rates averaged $0.33 \mathrm{~d}^{-1}$, ranging from 0.13 to $0.93 \mathrm{~d}^{-1}$. CR was significantly correlated with both PP and BBP. A significant correlation was found between $\mathrm{BBP}$ and $\mathrm{BOD}_{5}$, suggesting that the indigenous bacterial populations were strongly dependent on substrates measured by $\mathrm{BOD}_{5}$. The potentially labile fractions of TOC, as quantified by $\mathrm{BOD}_{5}$, were rapidly cycled by heterotrophic bacteria, within $\sim 4 \mathrm{~d}$ on average. With the exception of 6 to $8 \mathrm{wk}$ in early summer, the photic zone of this warm mesotrophic-eutrophic lake, with low inputs of allochthonous organic carbon, was net autotrophic. BBP and BGE values were high in comparison to those reported from even more eutrophic aquatic systems. Our results indicate that bacteria are by far the major biological agents of organic carbon cycling in Lake Kinneret, and contradict the general perception that the microbial loop plays a less important role in carbon cycling in eutrophic than in oligotrophic aquatic systems.
\end{abstract}

KEY WORDS: Bacterial production · Growth efficiency · Community respiration · Primary production · $\mathrm{BOD}_{5} \cdot$ Lake Kinneret

\section{INTRODUCTION}

The processes of phytoplankton photosynthetic carbon fixation (primary production, PP) and community respiration (CR) are responsible for major flows of carbon in the upper waters of most aquatic systems. Over the past 2 decades, it has become increasingly evident that heterotrophic bacterial uptake of dissolved organic carbon and heterotrophic respiration can also account for a further significant portion of total carbon flux within the photic zone of oceans and lakes (del Giorgio et al. 1997, Cole 1999, Biddanda \& Cotner 2002). The precise quantification of these processes, which largely determine ecosystem functions, has been and still remains a goal for marine and freshwater ecologists.

More than $70 \mathrm{yr}$ of sustained effort in measuring PP (Williams et al. 2002) has provided generally accepted estimates of global aquatic PP, mainly based on results achieved through variations of the ${ }^{14} \mathrm{C}$ method introduced by Steemann-Nielsen (1952). Although the importance of concomitant CR measurements has long been recognised, there were relatively few studies of $\mathrm{CR}$ in either marine or freshwater systems until the mid-1980s (but see Winberg 1971 for a summary of work in the USSR). Since then, improvements of the classical Winkler oxygen assay have permitted many measurements of planktonic community respiration 
with satisfactorily high sensitivity and precision, even in oligotrophic waters. Several other techniques for measuring CR have been applied less frequently. Some studies have also attempted to include phytoplankton respiration explicitly together with measurements of PP (e.g. Cole et al. 1992, Luz et al. 2002).

Heterotrophic bacterial productivity (bacterial biomass production, BBP) in natural waters has most often been measured by the uptake of either radioactive thymidine (Fuhrman \& Azam 1982) or leucine (Kirchman et al. 1985, Simon \& Azam 1989). Less frequently, BBP has been determined by following the outgrowth of bacteria in dilution cultures (Biddanda et al. 2001), or by counting the frequency of dividing cells (Hagström et al. 1979, Tuomi 1997). There is now a considerable amount of data on bacterial productivity and growth rates for many different aquatic systems. In contrast, reliable determinations of bacterial respiration (BR) in aquatic environments have proved to be more difficult (Jahnke \& Craven 1995).

Despite uncertainties inherent in all of the above methods, the application of existing techniques has led to an impressive characterization and quantification of these major carbon fluxes in many marine and freshwater systems. Such measurements have led to the perception of various aquatic environments as being net autotrophic or net heterotrophic (e.g. del Giorgio et al. 1997, Williams 1998, del Giorgio \& Duarte 2002, Robinson et al. 2002).

Here we report the results of a series of concomitant measurements of PP, CR and BBP made over a 2 yr period in Lake Kinneret, and examine the relationships between these parameters. We show that the photic zone of this lake is net autotrophic for most of the year, with a brief period of net heterotrophy in early summer. From these data we use a novel approach to estimate BGE for the lake's photic zone and suggest that determination of biological oxygen demand, $\mathrm{BOD}_{5}$, made in the same water samples, provided a quantitative measure of the labile fraction of the total organic carbon (TOC) pool.

\section{MATERIALS AND METHODS}

Study site. Lake Kinneret, the Biblical Sea of Galilee, is a warm monomictic lake with a surface area of $170 \mathrm{~km}^{2}$, and mean and maximum depths of 24 and $43 \mathrm{~m}$, respectively. Homothermy occurs between late December and early March, with minimum water temperatures usually $>14^{\circ} \mathrm{C}$. The lake is strongly stratified from about April to December, with maximum epilimnetic temperatures reaching 29 to $30^{\circ} \mathrm{C}$. With the onset of stratification, the hypolimnion rapidly becomes anoxic, with high concentrations of sulphide (5.0 to
$9.0 \mathrm{mg} \mathrm{l}^{-1}$ ) and ammonia ( 0.5 to $\left.1.3 \mathrm{mg} \mathrm{l}^{-1} \mathrm{~N}-\mathrm{NH}_{4}^{+}\right)$. The average annual PP over the period 1972 to 1993 was $610 \mathrm{~g} \mathrm{C} \mathrm{m}^{-2} \mathrm{yr}^{-1}$ (Berman et al.1995). Allochthonous inputs of organic carbon from riverine, littoral and benthic inflows and from dust deposition are about 5000 t C $\mathrm{yr}^{-1}$ or approximately $30 \mathrm{~g} \mathrm{C} \mathrm{m}^{-2} \mathrm{yr}^{-1}$ (A. Nishri pers. comm.), i.e. not more than about $5 \%$ of annual PP.

Methods. Samples were taken in the photic zone $(0$ to $15 \mathrm{~m}$ ) at a central, pelagic site, Stn A. Chlorophyll and PP were determined biweekly at depths of $0,1,2$, $3,5,7,10$ and $15 \mathrm{~m}$; CR biweekly at 1, 2, 5, 10 and $15 \mathrm{~m}_{;} \mathrm{BOD}_{5}$ as for $\mathrm{CR}$, but not at $5 \mathrm{~m} ; \mathrm{BBP}$ and bacterial numbers (BN) monthly at 1, 5, 10 and $15 \mathrm{~m}$. Linear integration was used to derive areal values for the photic water column. Note that not all parameters were measured on all occasions.

Chlorophyll concentrations were determined by acetone extraction and fluorometry (Holm-Hansen et al. 1965) and BN by DAPI staining and epifluorescence microscopy (Porter \& Feig 1980).

For PP we used the ${ }^{14} \mathrm{C}$ method (Steemann-Nielsen 1952 as modified by Berman \& Pollingher 1974), with a $3 \mathrm{~h}$ in situ incubation at Stn A.

Planktonic community respiration (CR) was measured in triplicate lake water samples in dark BOD bottles that were incubated in situ for $24 \mathrm{~h}$. Potentiometric titrations (azide modification of the Winkler method) with a high precision $( \pm 2.0 \mu \mathrm{l})$ 719S Metrohm Titrino titrator were made to determine oxygen concentrations. We used a factor of 0.3 to convert $\mathrm{mg} \mathrm{O}_{2} \mathrm{l}^{-1}$ to $\mathrm{mg} \mathrm{C}^{-1}$ (i.e. respiration coefficient of 0.8 ).

All lake water samples for $\mathrm{BOD}_{5}$ determinations were initially brought to oxygen saturation by intense stirring, prior to incubation for $5 \mathrm{~d}$ at $20^{\circ} \mathrm{C}$ in the dark. Initial and residual oxygen concentrations were measured by potentiometric titration as for $\mathrm{CR}$. BOD 5 was determined as $\mathrm{mg} \mathrm{O}_{2} \mathrm{l}^{-1}$ and transformed to carbon ( $\mathrm{mg} \mathrm{C}^{-1}$ ) using a respiratory coefficient of 0.8 .

We determined BBP using the leucine uptake method (Kirchman et al. 1985, Simon \& Azam 1989) as modified by Smith \& Azam (1993). Zero time controls were run for all samples. Leucine uptake was converted to carbon uptake using the conversion factors of Simon \& Azam (1989) with an isotope dilution factor of 2 .

\section{RESULTS}

In this paper we focus on data collected in the photic water layer (0 to $15 \mathrm{~m}$ ) of the lake from January 2001 until December 2002. During this period, average water temperatures in this layer varied from 15.9 to $30.2^{\circ} \mathrm{C}$ (Fig. 1). The general patterns of phytoplankton biomass (as chlorophyll, averaged for the photic layer) 


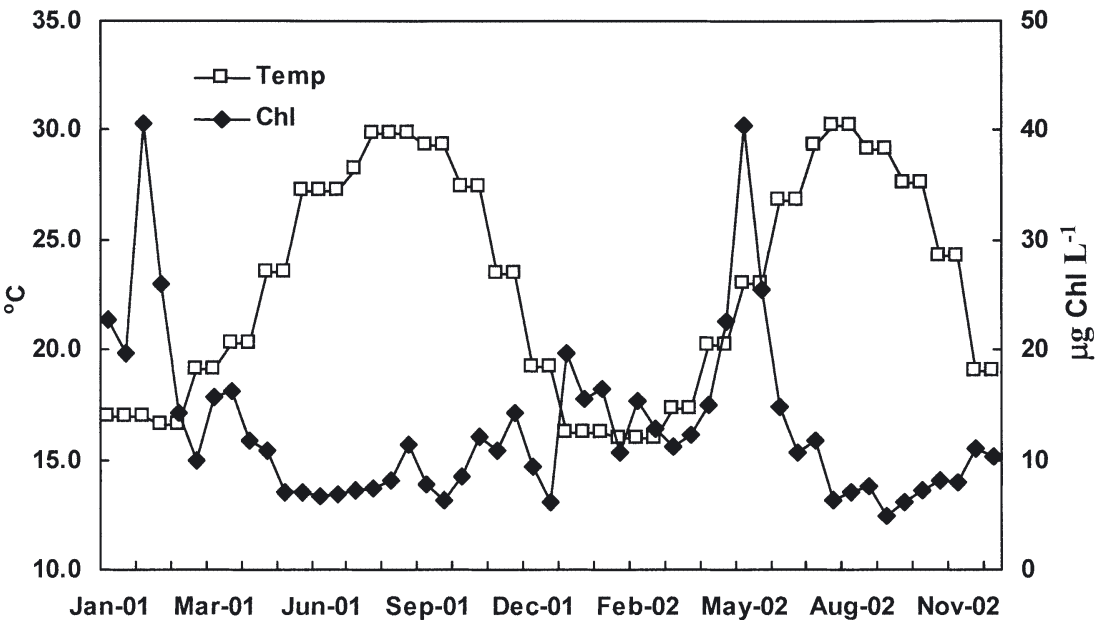

Fig. 1. Average chlorophyll and water temperatures in the epilimnion (0 to $15 \mathrm{~m}$ ) of Lake Kinneret from January 2001 to December 2002 (temperature data by courtesy of Kinneret Data Base)

\section{Community respiration}

CR averaged $1653 \pm 762 \mathrm{mg} \mathrm{C} \mathrm{m}^{-2} \mathrm{~d}^{-1}$, ranging from 343 (January 2002) to $3399 \mathrm{mg} \mathrm{C} \mathrm{m}^{-2} \mathrm{~d}^{-1}$ (May 2001). There were higher levels of CR in the early summer months from May through June that were not accompanied by a similar increase in PP (Fig. 2). There was less variation in the seasonal rates of $\mathrm{CR}$ than in chlorophyll or PP (Table 1). CR was significantly correlated with PP as a power function and, less strongly, with water temperature (Table 3).

\section{Bacterial abundance}

Bacterial cell counts in the epilimnion ranged from $1.9 \times 10^{6} \mathrm{ml}^{-1}$ to $7.9 \times 10^{6} \mathrm{ml}^{-1}$, are also shown in Fig. 1. The lake stratified and the hypolimnion became anoxic in early and mid-May in 2001 and 2002, respectively.

A summary of the parameters directly measured in our study: chlorophyll, PP, CR, BBP, BOD 5 and $\mathrm{BN}$, averaged for the entire period from January 2001 through December 2002 and separately for the winter-spring (January through June) and summerfall (July through December) seasons, is given in Table 1 . Some ratios between the above parameters are shown in Table 2.

\section{Primary production}

The annual pattern of PP during the 2 yr of this study (Fig. 2) did not show the late winter-spring peak associated with the dinoflagellate bloom that had occurred regularly for many years in Lake Kinneret (Berman et al. 1995). Other unusual features in the pattern of PP were the appearance of a secondary summer peak in AugustSeptember 2001 and again in the summer of 2002. Average PP for the period 2001 and 2002 was $1539 \pm 517 \mathrm{mgC}$ $\mathrm{m}^{2} \mathrm{~d}^{-1}$. There was no significant relationship between primary production and water temperatures.
Table 1. Seasonal and overall averages of chlorophyll $\left(\mathrm{Chl}_{i} \mathrm{mg} \mathrm{m}^{-2}\right)$, primary production $\left(\mathrm{PP} ; \mathrm{mg} \mathrm{C} \mathrm{m}^{-2} \mathrm{~d}^{-1}\right)$, bacterial biomass production (BBP; $\mathrm{mg} \mathrm{C} \mathrm{m}^{-2} \mathrm{~d}^{-1}$ ), community respiration $\left(\mathrm{CR}_{i} \mathrm{mg} \mathrm{C} \mathrm{m} \mathrm{d}^{-2} \mathrm{~d}^{-1}\right)$, biological oxygen demand $\left(\mathrm{BOD}_{5}\right.$; $\mathrm{mg} \mathrm{C} \mathrm{m}{ }^{-2}$ ) and bacterial numbers (BN; $10^{6}$ cells ml$^{-1}$ ) in Lake Kinneret

\begin{tabular}{|lrrrrrr|}
\hline & Chl & PP & BBP & CR & BOD $_{5}$ & BN \\
\hline $\mathbf{2 0 0 1}$ & & & & & & \\
Jan-Jun & 241 & 1748 & 1230 & 1754 & 7473 & 3.8 \\
Jul-Dec & 134 & 1543 & 1010 & 1683 & 5930 & 5.5 \\
$\mathbf{2 0 0 2}$ & & & & & & \\
Jan-Jun & 258 & 1549 & 605 & 1983 & 7024 & 4.7 \\
Jul-Dec & 121 & 1276 & 702 & 1192 & 5380 & 4.6 \\
Overall mean & $\mathbf{1 8 6}$ & $\mathbf{1 5 3 9}$ & $\mathbf{8 8 7}$ & $\mathbf{1 6 5 3}$ & $\mathbf{6 4 5 2}$ & $\mathbf{4 . 6}$ \\
No. of samples & 50 & 50 & 21 & 40 & 38 & 24 \\
\hline
\end{tabular}

Table 2. Ratios (\%) of phytoplankton and bacterial parameters in Lake Kinneret during 2001 and 2002. GPP: gross primary production; other abbreviations as in Table 1. A: PP $=0.7$ GPP; $\mathrm{B}: \mathrm{PP}=0.8 \mathrm{GPP}$

\begin{tabular}{|c|c|c|c|c|c|c|}
\hline & \multirow[t]{2}{*}{$\mathrm{BBP}: \mathrm{PP}^{\mathrm{a}}$} & \multirow[t]{2}{*}{$\mathrm{BBP}: \mathrm{CR}^{\mathrm{a}}$} & \multirow[t]{2}{*}{$\mathrm{BOD}_{5}: \mathrm{BBP}^{\mathrm{a}}$} & \multirow[t]{2}{*}{$\mathrm{CR}: \mathrm{PP}^{\mathrm{b}}$} & \multicolumn{2}{|c|}{ CR:GPP } \\
\hline & & & & & $\mathrm{A}$ & B \\
\hline \multicolumn{7}{|l|}{2001} \\
\hline Jan-Jun & 74.3 & 49.1 & 8.8 & 94.0 & 72.8 & 63.6 \\
\hline Jul-Dec & 64.8 & 69.1 & 4.9 & 106.0 & 91.4 & 79.9 \\
\hline \multicolumn{7}{|l|}{2002} \\
\hline Jan-Jun & 38.5 & 49.0 & 9.5 & 99.4 & 88.3 & 77.2 \\
\hline Jul-Dec & 66.5 & 52.8 & 8.2 & 117.3 & 92.5 & 80.9 \\
\hline Overall mean & 59.6 & 55.0 & 7.9 & 106.1 & 85.9 & 75.1 \\
\hline No. of samples & 21 & 18 & 16 & 40 & 40 & 40 \\
\hline
\end{tabular}




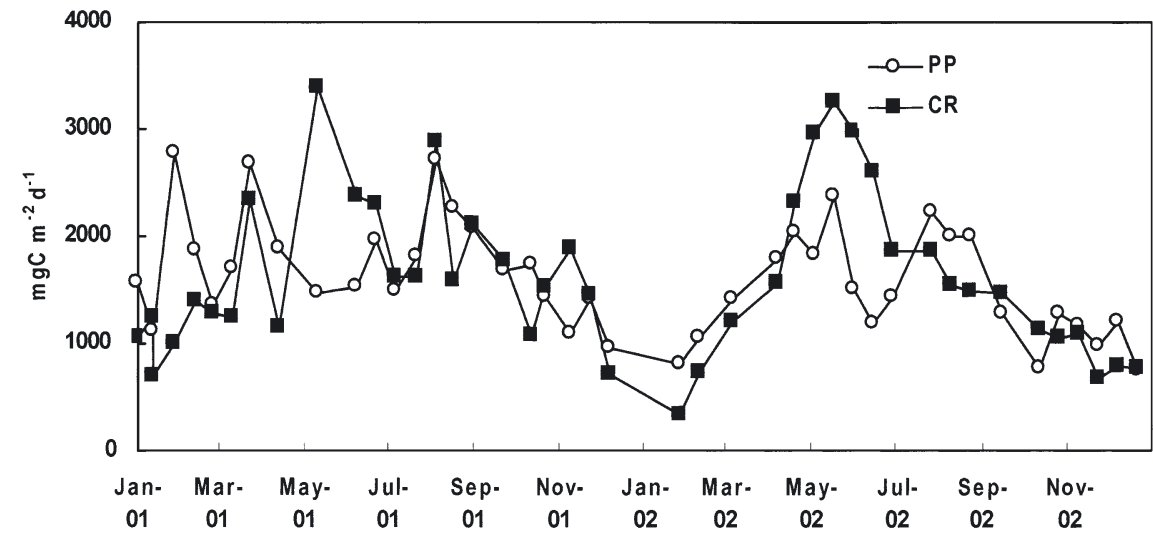

Fig. 2. Integrated epilimnetic primary production (PP) and community respiration (CR), January 2001 to December 2002

Table 3. Correlations between measured parameters. No significant correlations were found between BBP and PP; PP and $\mathrm{BOD}_{5} ; \mathrm{BBP}$ and temperature; or $\mathrm{PP}$ and temperature. Abbreviations as in Table 1

\begin{tabular}{|c|c|c|c|c|c|}
\hline \multicolumn{2}{|c|}{ Variables } & \multirow{2}{*}{$\begin{array}{l}\text { Eq. } \\
y=\end{array}$} & \multirow[t]{2}{*}{$r^{2}$} & \multirow[t]{2}{*}{$\mathrm{p}$} & \multirow[t]{2}{*}{$\mathrm{n}$} \\
\hline$y$ & $X$ & & & & \\
\hline $\mathrm{CR}$ & PP & $2.13 x^{0.89}$ & 0.36 & $<0.0001$ & 42 \\
\hline $\mathrm{CR}$ & Temp & $63.6 x^{1.002}$ & 0.21 & 0.002 & 42 \\
\hline $\mathrm{CR}$ & BBP & $282+1.65 x$ & 0.48 & 0.0009 & 18 \\
\hline $\mathrm{CR}$ & $\mathrm{BOD}_{5}$ & $-6281+918 \ln (x)$ & 0.21 & 0.005 & 34 \\
\hline $\mathrm{BBP}^{\mathrm{a}}$ & $\mathrm{BOD}_{5}$ & $5.07 x^{0.58}$ & 0.36 & 0.0135 & 15 \\
\hline $\mathrm{BBP}^{\mathrm{b}}$ & $\mathrm{BOD}_{5}$ & $1.03 x^{0.67}$ & 0.39 & 0.0003 & 30 \\
\hline
\end{tabular}

averaging $4.6 \times 10^{6} \mathrm{ml}^{-1}$. Bacterial abundance was low at the beginning of this study period but increased $>2$ fold during spring 2001 and thereafter remained relatively high throughout 2002; comparable high BN has not been observed in Lake Kinneret since 1998 (Fig. 3). During the years 1988 to 1994 the average concentrations of bacteria were similar $\left(4.0 \times 10^{6} \mathrm{ml}^{-1}\right.$ for the 0 to $10 \mathrm{~m}$ water column) but with greater variability, ranging from $5 \times 10^{5} \mathrm{ml}^{-1}$ to $2.3 \times 10^{7} \mathrm{ml}^{-1}$ (T. Berman unpubl.).

\section{Bacterial biomass production}

Bacterial biomass production (BBP), integrated to $15 \mathrm{~m}$ depth, averaged $887 \pm 469$ $\mathrm{mgC} \mathrm{m} \mathrm{C}^{-2} \mathrm{~d}^{-1}$, ranging from 300 to 2148 $\mathrm{mgC} \mathrm{m}{ }^{-2} \mathrm{~d}^{-1}$ over the $2 \mathrm{yr}$ period, with markedly higher levels during most of 2001 than in 2002 (Fig. 4). For all samples, BBP ranged from 16 to $151 \mathrm{mg} \mathrm{C} \mathrm{m}^{-3} \mathrm{~d}^{-1}$ and tended to be evenly distributed within the epilimnion at all seasons. On 2 occasions (16 June and 13 August 2002), exceptionally high rates of BBP were measured but we believe that these results were due to experimental error since all other parameters (chlorophyll, PP, CR, BOD) determined in the same water samples were not exceptional. Therefore we have excluded these results from our considerations here.

No significant relationships were observed between BBP and water temperatures, phytoplankton biomass (as chlorophyll) or PP. However, BBP was significantly correlated with CR (Table 3). Also, significant correlations were found between $\mathrm{BBP}$ and $\mathrm{BOD}_{5}$ either with data from all samples taken at 1 and $10 \mathrm{~m}$ depths or with data integrated for the photic water column (Table 3).

From January 2001 to December 2002, bacterial cellspecific productivity in the epilimnion, calculated as BBP divided by BN (DAPI counts), averaged $14.7 \mathrm{fg}$ C cell $^{-1} \mathrm{~d}^{-1}$, varying from 4.4 to $38.4 \mathrm{fg} \mathrm{C} \mathrm{cell}^{-1} \mathrm{~d}^{-1}$, with highest levels during spring and summer 2001.

Assuming a relatively high average carbon content of $30 \mathrm{fg}$ cell $^{-1}$ for bacterial cells in a mesotrophiceutrophic lake (Lee \& Fuhrman 1987, Fukuda et al. 1998) we calculated that, in the epilimnion of Lake Kinneret, the average carbon turnover time for a bacterial cell (defined as the time required to replace bacterial carbon biomass, or doubling time) fluctuated from 0.7 to $5.3 \mathrm{~d}$ (Fig. 4) with an overall average of $2.9 \pm 1.3 \mathrm{~d}$. Cell-specific growth rates averaged $0.33 \pm$ $0.22 \mathrm{~d}^{-1}$ and ranged from 0.93 to $0.13 \mathrm{~d}^{-1}$.

\section{Biological oxygen demand}

We measured $\mathrm{BOD}_{5}$ as a proxy for the readily labile fractions of organic carbon in the TOC pool (Osta-

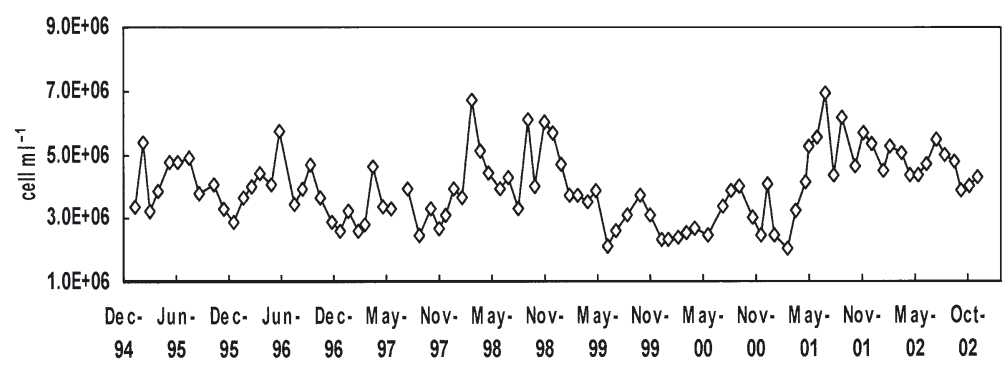

Fig. 3. Average bacterial numbers $(\mathrm{BN})$ in the epilimnion (0 to $15 \mathrm{~m})$, January 1994 to December 2002 


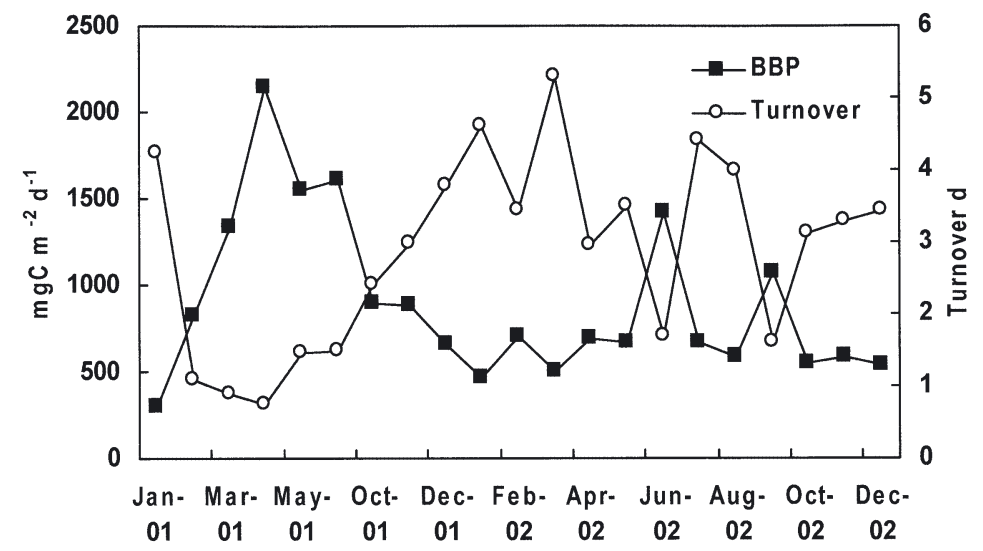

Fig. 4. Bacterial biomass production (BBP) and bacterial turnover time in the epilimnion (0 to $15 \mathrm{~m}$ ), January 2001 to December 2002
CR would have been between 86 and $75 \%$ of GPP (Table 2), ranging from 25 to $184 \%$ over the 2 yr period. Overall, for most of the year, the photic zone of the lake was net autotrophic, with a short period in May-June 2001 and 2002 of net heterotrophy (i.e. when CR > GPP).

For data integrated over $15 \mathrm{~m}, \mathrm{BBP}$ averaged $60 \%$ of PP (Table 2) and fluctuated from 27 to $141 \%$ of PP for all sampling dates. BBP averaged $55 \%$ of $\mathrm{CR}$, ranging from 21 to $97 \%$ (Table 2 ). These percentages were markedly higher in 2001 than in 2002 because of the drop in BBP in the latter year (Table 1, Fig. 4).

\section{Bacterial growth efficiencies}

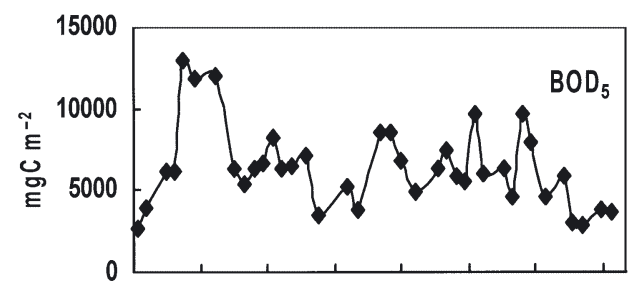

Jan- Apr- Jul- Nov- Feb- May- Sep- Dec-

$\begin{array}{llllllll}01 & 01 & 01 & 01 & 02 & 02 & 02 & 02\end{array}$

Fig. 5. Integrated epilimnetic $\mathrm{BOD}_{5}$, January 2001 to December 2002

penya 1971). $\mathrm{BOD}_{5}$ integrated for the upper $15 \mathrm{~m}$ water column averaged $6366 \pm 2473 \mathrm{mgC} \mathrm{m}^{-2}$ over the period of this study, varying from 2723 to $12908 \mathrm{mg} \mathrm{C}$ $\mathrm{m}^{-2}$ (Fig. 5). Generally higher $\mathrm{BOD}_{5}$ was found during the winter-spring period, when phytoplankton biomass was greatest (Table 1). Maximum $\mathrm{BOD}_{5}$ levels were observed during March-May 2001, probably reflecting the higher standing stocks of phytoplankton in that season.

\section{Relationships between parameters}

Within the photic zone, CR was on average $106 \%$ of measured $\mathrm{PP}$, ranging from 36 to $230 \%$, with 2 periods of elevated values in May-June 2001 and 2002 (Fig. 2). We postulate that PP measured by the ${ }^{14} \mathrm{C}$ method as used by us was close to net primary production (Cole et al. 1992, Marra 2002). If net primary production in Lake Kinneret was generally between 70 and $80 \%$ of gross primary production (GPP) (Berman \& Gerber 1980, Berman \& Kaplan 1984), then, on average,
BGE, defined as BBP divided by total bacterial carbon uptake, is a critical ecosystem parameter that is extremely difficult to measure directly in natural aquatic systems (del Giorgio \& Cole 1998, 2000). Total carbon uptake, or gross BBP, is the sum of net BBP plus bacterial respiration, $\mathrm{BR}$.

The range of BGE in Lake Kinneret was estimated from the set of measurements and assumptions in Table 4. We posited that our measurements of BBP and PP were close to net BBP (Biddanda \& Cotner 2002, M. Simon pers. comm.) and net PP (Cole et al. 1992, Marra 2002), respectively. In the example in Table 4, we used previously reported values of $20 \%$ daily carbon loss from GPP due to phytoplankton respiration, PR (Berman \& Kaplan 1984) together with minor amounts of exudation and photorespiration (Berman 1976). Since our measurement of CR reflected the total of bacterial, zooplankton and phytoplankton respiration $(\mathrm{CR}=\mathrm{BR}+\mathrm{ZR}+\mathrm{PR})$, it follows that $\mathrm{CR}-\mathrm{PR}=\mathrm{BR}+\mathrm{ZR}$.

Table 4. Bacterial growth efficiency (BGE) estimate from Lake Kinneret data. All values in $\mathrm{mg} \mathrm{C} \mathrm{m}^{-2} \mathrm{~d}^{-1}$. GPP, PP: gross and net primary production, respectively. CR, PR, BR, ZR: community, phytoplankton, bacterial and zooplankton respiration, respectively

\begin{tabular}{|c|c|c|c|}
\hline \multicolumn{4}{|c|}{ Conditions } \\
\hline $\mathrm{PR}=20 \% \mathrm{GPP}$ & $\mathrm{BR}=2 \mathrm{ZR}$ & $\mathrm{PR}=20 \% \mathrm{GPP}$ & $\mathrm{BR}=\mathrm{ZR}$ \\
\hline $\mathrm{PP}^{\mathrm{a}}$ & 1539 & $\mathrm{PP}^{\mathrm{a}}$ & 1539 \\
\hline $\mathrm{GPP}=1.25 \mathrm{PP}^{\mathrm{a}}$ & 1924 & $\mathrm{GPP}=1.25 \mathrm{PP}^{\mathrm{a}}$ & 1924 \\
\hline $\mathrm{PR}=20 \% \mathrm{GPP}$ & 385 & $\mathrm{PR}=20 \% \mathrm{GPP}$ & 385 \\
\hline $\mathrm{CR}^{\mathrm{a}}$ & 1653 & $\mathrm{CR}^{\mathrm{a}}$ & 1653 \\
\hline $\mathrm{CR}-\mathrm{PR}=\mathrm{BR}+\mathrm{ZR}$ & 1268 & $\mathrm{CR}-\mathrm{PR}=\mathrm{BR}+\mathrm{ZR}$ & 1268 \\
\hline $\mathrm{BR}$ (if $\mathrm{BR}=2 \mathrm{ZR}$ ) & 850 & $\mathrm{BR}$ (if $\mathrm{BR}=\mathrm{ZR}$ ) & 634 \\
\hline $\mathrm{BPP}^{\mathrm{a}}$ & 887 & $\mathrm{BPP}^{\mathrm{a}}$ & 887 \\
\hline $\mathrm{BGE}=\mathrm{BBP} /(\mathrm{BBP}+\mathrm{BR})$ & $51.1 \%$ & $\mathrm{BGE}=\mathrm{BBP} /(\mathrm{BBP}+\mathrm{BR})$ & $58.3 \%$ \\
\hline
\end{tabular}


Table 5. Lake Kinneret. Bacterial growth efficiency (BGE) calculated for various assumptions of phytoplankton respiration to gross primary production (PR:GPP) and ratios of bacterial to zooplankton respiration (BR:ZR)

\begin{tabular}{|llc|}
\hline & $\begin{array}{c}\text { Conditions } \\
\text { BR:ZR }\end{array}$ & BGE (\%) \\
\hline PR $=30 \%$ GPP & BR $=$ ZR & 64.1 \\
PR $=30 \%$ GPP & BR $=2$ ZR & 57.1 \\
PR $=30 \%$ GPP & BR $=3$ ZR & 54.3 \\
PR $=20 \%$ GPP & BR $=$ ZR & 58.3 \\
PR $=20 \%$ GPP & BR $=2$ ZR & 51.1 \\
PR $=20 \%$ GPP & BR $=3$ ZR & 48.3 \\
PR $=15 \%$ GPP & BR $=$ ZR & 48.9 \\
PR $=15 \%$ GPP & BR $=2$ ZR & 56.2 \\
PR $=15 \%$ GPP & BR $=3$ ZR & 46.1 \\
PR $=10 \%$ GPP & BR $=$ ZR & 54.5 \\
PR $=10 \%$ GPP & BR $=2$ ZR & 47.2 \\
PR $=10 \%$ GPP & BR $=3$ ZR & 44.4 \\
\hline
\end{tabular}

In Table 4, we used ratios of BR:ZR of either 1 or 2 . Combining Lines 6 and 7 in Table 4 then gave a direct estimate of BGE, in this case, 51.1 or $58.3 \%$, depending on the ratio $\mathrm{BR}: \mathrm{ZR}$.

Table 5 shows BGE values, averaged for 2001-2002, obtained for a range of ratios of PP:GPP and BR:ZR, with PP varying from 70 to $90 \%$ of GPP and BR varying from $\mathrm{BR}=\mathrm{ZR}$ to $\mathrm{BR}=3 \mathrm{ZR}$. Rather surprisingly, the estimated BGE varied only from 44 to $64 \%$, over this fairly wide span for PP:GPP and BR:ZR.

\section{DISCUSSION}

During this study, the seasonal development of phytoplankton in Lake Kinneret differed from the fairly regular annual cycle that prevailed from 1972 to 1994 (Berman et al. 1998). Phytoplankton maxima in February 2001 and May 2002 (Fig. 1) were due to Aulacoseira granulata and Peridinium gatunense, respectively. In 2002, after a lapse of 2 yr there was a moderate winter-spring dinoflagellate bloom similar to the 'normal' pattern (T. Zohary pers. comm.). A clear division between a $P$. gatunense bloom season and a chlorophyte-dominated summer season was a basic feature in attempts to quantify carbon flux in the Lake Kinneret system (Serruya et al. 1980, Stone et al. 1993, Hart et al. 2000). Unlike previous years, during the summers of 2001 and 2002 the phytoplankton was characterized by a mixture of cyanobacteria, chlorophytes and diatoms. The average values of PP for the years 2001 and 2002 (Table 1) were about 20\% lower than the multi-year average PP from 1972 to 2002 (Y. Yacobi pers. comm.).

The pattern of bacterial abundance (Fig. 3) may also reflect the changing state of this ecosystem, with rela- tively higher levels in 1998 and again from the summer of 2001, without any clear annual cycles such as were observed in measurements made from 1989 to 1994 (not shown). We have no data to indicate whether there were any changes in the phylogenetic composition of the lake bacterial community during this period.

\section{CR and GPP; net autotrophy and net hetrotrophy in the phototrophic zone}

Similarly to observations in other aquatic systems (del Giorgio \& Peters 1994, Iriarte et al. 1996, Carignan et al. 2000) we found a significant power regression for CR with PP in Lake Kinneret (Table 3). CR also showed a significant power correlation to water temperatures, as has been reported elsewhere (Iriarte et al.1996), although only about $20 \%$ of the variability in CR could be explained by changes in temperature.

Based on the average for the period from January 2001 to December 2002, CR in the photic zone accounted for 75 to $86 \%$ of GPP, when total carbon losses by phytoplankton respiration and exudation from GPP were between 20 and 30\% (Berman \& Gerber 1980, Berman \& Kaplan 1984). This level of CR would imply that between 14 to $25 \%$ of annual GPP sedimented out as particulate organic carbon (POC) from the phototrophic water layer, i.e. 100 to $150 \mathrm{~g} \mathrm{C}$ $\mathrm{m}^{-2} \mathrm{yr}^{-1}$ or $\sim 17000$ to $25000 \mathrm{t}$ organic $\mathrm{C} \mathrm{yr}^{-1}$ for a lake surface area of $170 \mathrm{~km}^{2}$. These amounts of sedimented organic carbon are compatible with estimates of TOC exported from the trophogenic layer, based on calculations of the amounts of $\mathrm{NH}_{4}{ }^{+}$and $\mathrm{H}_{2} \mathrm{~S}$ generated within the hypolimnion by mineralization of organic matter (Nishri et al.1998, A. Nishri pers. comm.).

In both 2001 and 2002, CR exceeded PP and GPP for only about 2 mo in early summer, coincident with the most rapid warming of the water mass, and towards the end of the late winter-spring phytoplankton bloom (Figs. $1 \& 2$ ). This appears to be the only period when the photic zone of Lake Kinneret was net heterotrophic. As noted above, the total amounts of organic carbon entering the lake from the River Jordan and minor river inflows, from littoral vegetation, benthos and atmospheric deposition are very small compared to the total amounts of these pools in the lake water (A. Nishri pers. comm.). Thus, $>95 \%$ of TOC in this lake derives from autochthonous sources, in contrast to many lakes in which allochthonous organic carbon inputs support considerable heterotrophic activity (Cole et al. 2000).

A general pattern of increasing CR:GPP with increasing oligotrophy was suggested by del Giorgio \& Peters (1994) and by del Giorgio et al. (1997), who posited that lakes tend to become net heterotrophic when chlorophyll levels fall to $<15 \mu \mathrm{g} \mathrm{l}^{-1}$ or to PP 
$<120 \mu \mathrm{g} \mathrm{C} \mathrm{l}^{-1} \mathrm{~d}^{-1}$. Note, however, that the average, photic zone chlorophyll concentrations and PP in Lake Kinneret during our study were $12.4( \pm 7.5) \mathrm{\mu g} \mathrm{l}^{-1}$ and $103 \pm 34 \mu \mathrm{g} \mathrm{Cl}^{-1} \mathrm{~d}^{-1}$, respectively, with lengthy periods of chlorophyll concentrations $<15 \mu \mathrm{g} \mathrm{l}^{-1}$ (Fig. 1) and rates of PP below $100 \mu \mathrm{g} \mathrm{C} \mathrm{l}^{-1} \mathrm{~d}^{-1}$. Nevertheless, as noted above, the phototrophic zone of the lake was net autotrophic during most of the year.

Our present observations on Lake Kinneret do not fit the general pattern of net autotrophic and net heterotrophic aquatic systems proposed by del Giorgio et al. (1997). Another exception to the trend suggested by del Giorgio et al. (1997) was reported by Carignan et al. (2000), who found a predominance of net autotrophy in 12 oligotrophic to mesotrophic Canadian shield lakes, with a median CR:GPP ratio of 0.59.

We used a respiration coefficient of 0.8 to convert CR from oxygen to carbon, and thereby obtained lower carbon respiration rates than would have been obtained with the frequently used respiration coefficient of 1.0 (del Giorgio et al. 1997, Biddanda et al. 2001). As pointed out by Geider (1997), a respiration coefficient of 0.8 is probably more accurate for natural aquatic environments where the respiration of organic matter includes proteins and lipids in addition to carbohydrates. Recently, Robinson et al. (2002) experimentally determined a respiratory coefficient of 0.8 for 11 samples in the eastern Atlantic Ocean.

Our estimates for GPP are considerably lower than those reported for Lake Kinneret by Luz et al. (2002) using an ${ }^{18} \mathrm{O}$ oxygen isotope method. At present we have no explanation for this discrepancy, although the question of the value assigned to the photosynthetic quotient in order to transform $\mathrm{O}_{2}$ to $\mathrm{C}$ in this method is critical.

\section{BBP and PP}

White et al. (1991) listed bacterial growth rates ranging from 0.017 to $8.7 \mathrm{~d}^{-1}$ for 10 eutrophic and 14 mesotrophic lakes, and Cole \& Pace (1995) reported bacterial specific growth rates from 0.02 to $4.6 \mathrm{~d}^{-1}$ for a variety of freshwater and marine locations. The average bacterial growth rates for photic zone bacteria in Lake Kinneret $\left(0.46 \mathrm{~d}^{-1}\right.$ in $2001 ; 0.23 \mathrm{~d}^{-1}$ in 2002; $0.33 \mathrm{~d}^{-1}$ for all samples) were well within these ranges and similar to growth rates measured in lake water cultures by Pinhassi \& Berman (2003). Nevertheless, the levels of both volumetric BBP and areal BBP measured in Lake Kinneret were at the high end of rates reported for a wide variety of aquatic environments (Table 6). This seems reasonable, considering that Lake Kinneret is mesotrophic-eutrophic, with higher phytoplankton standing stocks and warmer water than many (but not all) of the aquatic systems listed in Table 6 . The average BBP values observed during this study were remarkably similar to those measured in Lake Kinneret during the period 1998 to 1999 using the same ${ }^{14} \mathrm{C}$ leucine uptake method (average: $913 \pm 619 \mathrm{mg} \mathrm{C} \mathrm{m}^{-2}$ $\mathrm{d}^{-1}$ ) and to BBP determined by ${ }^{3} \mathrm{H}$ thymidine uptake during the years 1988 to mid-1991 (average: $994 \pm$ $1247 \mathrm{mg} \mathrm{C} \mathrm{m}^{-2} \mathrm{~d}^{-1}$; T. Berman unpubl.).

We calculated bacterial cell-specific growth rates and turnover times (Fig. 4) on the basis of total BN as given by DAPI staining. However, as has been observed in Lake Kinneret (Berman et al. 2001) and elsewhere (Choi et al. 1999, Bernard et al. 2000, Søndergaard \& Danielsen 2001), only a small proportion of the total bacterial population (perhaps $~ 20 \%$ as a conservative estimate) appear to be strongly metabolically active. If this is so, then the average cellular uptake, turnover time and cell-specific growth rate for 'active bacteria' in this lake would be $73.6 \mathrm{fg} \mathrm{C}^{-1} \mathrm{cell}^{-1}$ $\mathrm{d}^{-1}, 0.57 \mathrm{~d}$ and $1.22 \mathrm{~d}^{-1}$, respectively.

A partial explanation for the very rapid growth rates attributed to 'active' bacterial cells may be the observation that 'no more than $\sim 20 \%$ of bacterial cells are active at any given time' (Berman et al. 2001). It is feasible that bacterial cells may be strongly active only intermittently. Thus, some of the inactive (or weakly active) cells observed at one point in time may subsequently become active (Choi et al.1999, Berman et al. 2001), while previously active cells may cease activity. In this manner, all the DAPI-stained cells in the community may indeed be active but, on average, for only $20 \%$ of the day. In this case, estimates of the daily growth rates for each cell in the bacterial community become more reasonable. Of course, it is unlikely that all DAPI-counted bacteria are metabollically active or that 'activity' is an all-or-none phenomenon.

An important consideration is the question of whether BBP determinations using either radioactive thymidine or leucine give gross or net measurements (or something between). In the present work, similarly to that of Biddanda \& Cotner (2002), Ducklow (2000) and M. Simon (pers. comm.), we have taken the radioactive ${ }^{14} \mathrm{C}$-leucine method with a $1 \mathrm{~h}$ incubation time as used here to give a close approximation of net bacterial production.

For the period of this study, the average BBP:PP measured for the photic water column was $60 \%$ (Table 2 ) and BBP was 42 or $48 \%$ of GPP, depending on the assumed daily phytoplankton respiration and exudation losses of either 30 or $20 \%$ (Berman \& Gerber 1980, Berman \& Kaplan 1984). A pioneering study by Winberg (1971), based on dark ${ }^{14} \mathrm{C}$-uptake and $\Delta \mathrm{O}_{2}$ measurements of BBP and GPP, respectively, indicated a wide variation of BBP to GPP, from 16 to $78 \%$, for a series of Russian lakes ranging from oligotrophic to 
Table 6. Bacterial biomass production (BPP) in a variety of aquatic environments. L: leucine method; T: thymidine method; DC: dilution culture method

\begin{tabular}{|c|c|c|c|c|}
\hline Location & $\begin{array}{c}\text { BBP } \\
\mathrm{mg} \mathrm{C} \mathrm{m}^{-2} \mathrm{~d}^{-1}\end{array}$ & $\begin{array}{c}\mathrm{BBP} \\
\mathrm{mg} \mathrm{C} \mathrm{m}^{-3} \mathrm{~d}^{-1}\end{array}$ & Method & Source \\
\hline Aquatic systems & $118-2439$ & $26.3(0.4-150)$ & $\mathrm{T}, \mathrm{L}$ & Cole et al. (1988) \\
\hline Freshwater & - & $45.3(0.5-302)$ & $\mathrm{T}$ & White et al. (1991) \\
\hline Marine & - & $18.0(<0.1-336)$ & $\mathrm{T}$ & White et al. (1991) \\
\hline Estuarine and coastal waters & - & $356(0.03-23,767)$ & $\mathrm{T}$ & White et al. (1991) \\
\hline Chesapeake Bay & - & $20.0-280$ & $\mathrm{~T}$ & Jonas \& Tuttle (1990) \\
\hline Mississippi River Plume & - & $5.0-90$ & $\mathrm{~T}, \mathrm{~L}$ & Chin-Leo \& Benner (1992) \\
\hline Gulf of Mexico (shelf, slope) & - & $23.5: 19.0$ & $\mathrm{~T}, \mathrm{~L}$ & Biddanda et al. (1994) \\
\hline SubArctic, NE Pacific & - & $0.5-4.5$ & $\mathrm{~T}, \mathrm{~L}$ & Sherry et al. (1999) \\
\hline Cretan Sea (NE Mediterranean) & $(60-131)^{a}$ & $1968^{\mathrm{d}}$ & $\mathrm{L}$ & Van Wambeke et al. (2000) \\
\hline Weddell, Scotia Seas & - & $0.12(0.02-0.34)$ & $\mathrm{L}$ & Moran et al. (2001) \\
\hline Tuamota Atoll Lagoon & - & $1.0-43.6$ & $\mathrm{~T}$ & Torreton et al. (2002) \\
\hline Humbold Current System (coastal) & $(70-1722)^{\mathrm{b}}$ & - & $\mathrm{T}$ & Troncoso et al. (2003) \\
\hline Humbold Current System (oceanic) & $(97-850)^{b}$ & - & $\mathrm{T}$ & Troncoso et al. (2003) \\
\hline L. Hylke, Denmark & 1520,0 & - & $\mathrm{T}$ & Riemann \& Søndergaard (1986) \\
\hline Frederiksborg Slotsso & 6640,0 & - & $\mathrm{T}$ & Riemann \& Søndergaard (1986) \\
\hline Lake Michigan & $652^{\mathrm{a}}$ & $28.9^{\mathrm{c}}(0.2-90)$ & $\mathrm{T}$ & Scavia \& Laird (1987) \\
\hline Lake Plußsee (photic zone, Apr-Oct) & - & $9.6(0.9-40.6)$ & $\mathrm{T}$ & Chrost \& Rai (1994) \\
\hline Lake Constance & 78,0 & $0.24-96$ & $\mathrm{~T}, \mathrm{~L}$ & Gude (1990) \\
\hline Lake Constance & $(199-954)^{\mathrm{C}}$ & - & $\mathrm{L}$ & Simon et al. (1998) \\
\hline Lake Paul & 50,0 & - & $\mathrm{L}$ & Pace \& Cole (1994) \\
\hline Crystal Lake & 51,0 & - & $\mathrm{L}$ & Pace \& Cole (1994) \\
\hline Lake Trout & 48,0 & - & $\mathrm{L}$ & Pace \& Cole (1994) \\
\hline Lawrence Lake & $134-597$ & - & $\mathrm{T}$ & Coveney \& Wetzel (1995) \\
\hline 9 Minnesota lakes (oxic layer) & - & $12.6(2.6-17.0)$ & $\mathrm{L}$ & Cole \& Pace (1995) \\
\hline 9 Minnesota lakes (anoxic layer) & - & $20.6(1.1-47.0)$ & $\mathrm{L}$ & Cole \& Pace (1995) \\
\hline 10 Minnesota lakes & - & $4.3-19.6$ & DC & Biddanda et al. (2001) \\
\hline Lake Superior & - & $0.58-1.15$ & $\mathrm{DC}$ & Biddanda et al. (2001) \\
\hline East Long Lake & - & $8.1 \pm 5.0$ & $\mathrm{~L}$ & Cole et al. (2002) \\
\hline Lake Michigan & - & $0.5-5.0$ & $\mathrm{~L}$ & Biddanda \& Cotner (2002) \\
\hline Lake Kinneret (1988-1991) 0-20 m & $994 \pm 1247$ & 50,0 & $\mathrm{~T}$ & T. Berman (unpubl.) \\
\hline Lake Kinneret (2001-2002) 0-15 m & $913 \pm 619$ & 61,0 & $\mathrm{~L}$ & T. Berman (unpubl.) \\
\hline Lake Kinneret (1998-1999) 0-15 m & $887 \pm 469$ & $56.4(16.0-151)$ & $\mathrm{L}$ & This paper \\
\hline
\end{tabular}

eutrophic. The levels of BBP relative to GPP in Lake Kinneret are considerably higher than those recorded by Simon et al. (1998) in mesotrophic Lake Constance, but similar to those measured by Inkina (1985) for Lake Miastro. Both these lakes have levels of primary production roughly similar to those in Lake Kinneret. Scavia \& Laird (1987) observed that annual bacterial carbon demand, i.e. gross BBP, was $65 \%$ of PP in Lake Michigan. Schwaerter et al. (1988) listed estimates of bacterial gross production ranging from 20 to $80 \%$ of phytoplankton gross production in lakes and from 24 to $60 \%$ in marine environments. Cole et al. (1988), in an extensive cross-system review of bacterial productivity, found that BBP to PP was generally between 20 and $40 \%$ in most aquatic environments. In a recent study of the Antofagusta coastal and oceanic regions within the Humbold Current off Chile, Troncoso et al. (2003) reported extremely high BBP:PP, ranging from 63 to $478 \%$. Most marine studies have found much lower values; for instance, Ducklow et al. (2002) brought evidence to show that levels of BBP were previously overestimated in the North Atlantic Ocean and that BBP:PP could not be $>20 \%$ in this oligotrophic marine system.

The relatively high percentage of BPP to PP that we observed implies that total bacterial carbon demand (gross BBP) in the trophogenic zone of Lake Kinneret was close to, or at times even in excess of GPP. If we take average annual values for BGE of 51 or $57 \%$ (Table 5, with BR $=2 \mathrm{ZR}$ ) and a ratio of BBP:GPP of 48 or $42 \%$ (depending on whether PR was taken to be 20 or $30 \%$ ), then the proportion of GPP taken up by bacterial carbon demand was between 73 and $94 \%$ averaged over the 2 yr study. These are high but by no means impossible levels for gross BBP:GPP. The total bacterial carbon uptake by bacteria and by secondary and tertiary consumers can exceed GPP because of recyling within the system (Strayer 1988), as was shown to be the case for Lake Michigan (Scavia 1988). Our data confirm previous indications that bacteria in 
Lake Kinneret are by far the major agents of organic carbon cycling in this ecosystem (Stone et al. 1993, Hadas \& Berman 1998, Hart et al. 2000).

Our finding that BBP was significantly correlated with CR (Table 3) would also imply that bacterial respiration is an important component of planktonic CR in this lake (as indicated in Table 4) similar to many (Hopkinson et al. 1989, Jahnke \& Craven 1995, Sherry et al. 1999), but not all (Williams 1981, Sherry et al.1999), aquatic systems.

Although many investigators have observed a strong relationship between BBP and temperature in aquatic environments (e.g. Iriberri et al. 1985, White et al. 1991, Shiah \& Ducklow 1994, Simon et al. 1998, Sherry et al. 1999), no such relationship above $10^{\circ} \mathrm{C}$ was found by Scavia \& Laird (1987) in Lake Michigan or by Cole \& Pace (1995) in 9 North American lakes, and none was evident in Lake Kinneret.

Unlike previous observations in Lake Kinneret (Berman et al. 2001) and elsewhere (e.g. Cole et al. 1988, White et al. 1991), no correlation was found between BBP and primary production, or between BBP and chlorophyll. Pace \& Cole (1994) also reported no significant correlation between BBP and PP in 3 Wisconsin lakes and suggested that other factors such as nutrient recyling and phytoplankton loss rates could be more significant than levels of PP in determining BBP.

\section{Estimating BGE}

For a direct evaluation of BGE, both BBP and BR need to be known. These parameters can be determined relatively easily in experiments with bacterial cultures, but in natural aquatic systems reliable measurement of BR is problematic (Jahnke \& Craven 1995). Experimental measurements of BGE in batch and chemostat cultures have shown that this parameter can fluctuate widely, depending on specific organism and growth conditions (see references in del Giorgio \& Cole 1998, 2000). Early estimations of BR in marine and freshwater (Hobbie \& Crawford 1969) that were based on the addition of trace quantities of radioactive substrates (usually ${ }^{14} \mathrm{C}$-glucose or ${ }^{14} \mathrm{C}$ amino acids) tended to give relatively low $\mathrm{BR}$ and therefore relatively high BGE. For example, Williams (1970) reported a BGE of 67 and $78 \%$ for marine bacteria metabolizing glucose or amino acids, respectively, and Berman et al. (1979) found BGEs ranging from 39 to $75 \%$ in Lake Kinneret based on ${ }^{14} \mathrm{C}$-glucose uptake experiments. The results of such experiments are now thought to have generally underestimated BR and overestimated BGE, because they were based on bacterial utilization of a single or, at most, a few readily available substrates, whereas bacteria in the real life environment presumably exploit a broad spectrum of substrates of variable availability (del Giorgio \& Cole 1998, 2000).

Because of the difficulties of direct measurement of $\mathrm{BR}$, in more recent studies of bacterially mediated carbon flux in natural aquatic environments, some investigators have used assumed BGE values based on the literature (e.g. Scavia \& Laird 1987, Strayer 1988, Baines \& Pace 1991, Ducklow \& Carlson 1992, Stone et al. 1993, Coveney \& Wetzel 1995, Hart et al. 2000). Others have quantified BR directly by following the increase in ambient dissolved inorganic carbon (Cole et al. 1989) or, more frequently, by determining $\mathrm{O}_{2}$ uptake in water samples that were pre-filtered in order to exclude phytoplankton and protozoans (e.g. Hopkinson et al. 1989, Biddanda et al. 1994, 2001, Roland \& Cole 1999, Sherry et al. 1999, Rivkin \& Legendre 2001, Smith \& Kemp 2003). Unfortunately, the method of estimating BR using filtration followed by a lengthy (usually $\sim 24 \mathrm{~h}$ ) incubation step radically changes the environment in which BR determinations are made by altering the patterns of organic carbon cycling in these samples. Additionally, there is the problem of 'mixed' timescales, whereby BBP is measured 'instantaneously' at the beginning of the experiment, while BR requires a prolonged incubation (see Roland \& Cole 1999). Thus, the validity of BR estimates made in prefiltered samples may be compromised.

Recently, Toolan (2001) successfully applied coulometric respiration measurement on filtered and unfiltered samples to directly estimate BR and CR with only $\sim 10 \mathrm{~h}$ incubation. Measurements of electron transport system (ETS) activity (Packard 1971) have also been used to quantify planktonic respiration. In Lake Kinneret, ETS activity in GF/C-filtered samples was found to correlate reasonably well with $\Delta \mathrm{O}_{2}$ and hydrolytic enzyme activity but not with BBP (Berman et al. 2001).

For logistic reasons (i.e. lack of time and money), we were unable to use any of the above methods to estimate $\mathrm{BR}$, and in the present study we applied a different approach to derive BGE. By using the relatively robust determinations of $\mathrm{PP}, \mathrm{BBP}$ and $\mathrm{CR}$, and reasonable assumptions based on the literature for the possible ranges of $\mathrm{PR}$ (from 20 to $30 \%$ of GPP) and the ratio of BR:ZR (0.33 to 1), we calculated a range of potential average values for BGE in the photic zone of Lake Kinneret (Tables 4 \& 5).

In their very extensive review on BGE in natural waters, del Giorgio \& Cole (1998) showed that reported values for this parameter tended to be lowest in rivers, increased somewhat in oceans, then in lakes, and were highest in estuaries. The median BGE for their sample of about 20 lakes was $\sim 28 \%$, the median BGE for 6 estuaries was $\sim 34 \%$. Kristiansen et al. (1992) deter- 
mined a mean BGE of $31 \%$ in a small, eutrophic lake, Frederiksborg Slotsø. In a recent study in Lake Superior and 10 small Minnesota lakes with chlorophyll concentrations ranging from 0.6 to $52.7 \mu \mathrm{g} \mathrm{l}^{-1}$, Biddanda et al. (2001) reported BGE from 5 to $39 \%$, increasing from oligotrophic to eutrophic systems. In Chesapeake Bay, Smith \& Kemp (2003) measured a range of BGE from 20.4 to $41.3 \%$, with spatial variations in efficiencies apparently increasing with increasing nutrient concentrations.

Our estimated BGE values (Table 5) were distinctly higher than the $<10$ to $25 \%$ (del Giorgio et al. 1997) or $<30 \%$ (Cole 1999) reported for a series of freshwater and marine systems, but more similar to those cited for productive estuarine systems (see also Table 1 in del Giorgio \& Cole 2000). Applying the relationship BGE = $0.02 \times \mathrm{PP}^{0.41}$ suggested by del Giorgio et al. (1997) to the Lake Kinneret data, we obtained a BGE of $40 \%$.

Rivkin \& Legendre (2001) analyzed the results of studies from a range of polar, temperate and tropical marine systems in which BGE was computed from BBP and BR (measured by the uptake of DOC or of $\mathrm{O}_{2}$ in filtered samples), and noted a significant inverse relationship between BGE and water temperature. We did not find any relationship between BGE and temperature in Lake Kinneret. If the results shown by Rivkin \& Legendre (2001) in their Fig. 1 apply also to freshwater, then they would imply that our BGE determinations are greatly overestimated for this warm lake.

\section{BOD $_{5}$ as a measure of labile organic carbon}

The measurement of BOD is a commonplace and 'classical' indicator of water quality. However, with the exception of work in the former Soviet Union and Eastern European countries (e.g. Ostapenya 1971), BOD measurements have rarely been applied to ecological studies of aquatic environments.

Although some of the $\mathrm{O}_{2}$ uptake in the BOD bottles was due to dark respiration of phytoplankton and did not reflect direct extracellular hydrolysis of organic substrates by bacteria, nevertheless we found a highly significant correlation between $\mathrm{BBP}$ and $\mathrm{BOD}_{5}$ (Table 3). This result suggests that the indigenous bacterial populations were strongly dependent on the labile organic fractions measured by $\mathrm{BOD}_{5}$. Close to $40 \%$ of the variability of BBP could be attributed to variability in $\mathrm{BOD}_{5}$. In addition, $\mathrm{CR}$ was significantly correlated with $\mathrm{BOD}_{5}$ (Table 3 ). These relationships strengthen the premise that $\mathrm{BOD}_{5}$ can indeed serve as a useful and quantitative measure of the labile organic carbon pool in natural water bodies.

During the years 2001 and 2002, DOC concentrations in the epilimnion of Lake Kinneret varied from about 3.5 to $5 \mathrm{~g} \mathrm{C} \mathrm{m}^{-3}$, with an average of $\sim 50 \mathrm{~g} \mathrm{C} \mathrm{m}^{-2}$ for the trophogenic water column. The DOC pool comprised $\sim 75 \%$ of total organic carbon (TOC) (A. Parparov pers. comm.). The average integrated value for $\mathrm{BOD}_{5}$ down to $15 \mathrm{~m}$ was $6.4 \pm 2.5 \mathrm{~g} \mathrm{C} \mathrm{m}^{-2}$. Thus, the labile fraction of organic carbon as inferred by our $\mathrm{BOD}_{5}$ measurements was only about 13 and $10 \%$ of the DOC and TOC pools, respectively.

The idea that BBP is dependent on readily available DOC is not new (e.g. Søndergaard et al. 1995). Søndergaard \& Middleboe (1995) documented the levels of the labile DOC fraction of the total DOC pool in a variety of aquatic systems. In a recent study, Moran et al. (2001) found that BBP was strongly correlated to ambient DOC in Antartic waters. We suggest, however, that BBP is dependent not only on the dissolved but also on some of the particulate organic carbon fractions that are readily hydrolyzed by extracellular enzymes.

The concentration of labile organic carbon given by $\mathrm{BOD}_{5}$ divided by the total bacterial carbon demand (i.e. BBP + BR) gives an estimate of the turnover time of the labile pool of TOC taken up by heterotrophic bacteria. Using our measured values for BBP and an estimated BGE of $50 \%$, we calculated a turnover time of $\sim 4 \mathrm{~d}$ for the labile fractions of TOC utilized by heterotrophic bacteria, with fastest rates occurring in summer-fall 2001. Using respiration measurements, Parparov et al. (1998) estimated that the average turnover time for POC in Lake Kinneret was about $14 \mathrm{~d}$. Both these rates are much faster than the turnover times of 75 to $120 \mathrm{~d}$ for biodegradable DOC measured in batch cultures and in a bio-reactor in samples from Lake Esröm, Denmark, by Søndergaard et al. (2000). At least part of the discrepancy between these estimates may lie in differences in biological availability of the TOC pool components in the 2 systems.

\section{Conclusions}

The values that we measured for $\mathrm{PP}, \mathrm{CR}, \mathrm{BBP}$, and our derived BGE give a consistent picture of the major carbon flows in the epilimnion of Lake Kinneret, including sedimentation of POC to the hypolimnion. In contrast to many previously described freshwater systems, the phototrophic zone of this monomictic, large, warm lake, with negligible amounts of allochthonous TOC input, was net autotrophic for most of the year. An independent confirmation of the patterns of net autotrophy/net heterotrophy reported above for this lake could be obtained by means of a gas-flux model (e.g. Cole et al. 2000), but this approach has yet to be applied to this lake (A. Nishri pers. comm.). Measured rates of BBP were high relative to those reported for more oligotrophic and cooler aquatic environments, 
and they even exceeded BBP values from more eutrophic systems. Both BBP:PP and average BGE were higher than those reported for most other water bodies. The potentially labile pools of TOC, as quantified by $\mathrm{BOD}_{5}$, were rapidly cycled by heterotrophic bacteria, within about $4 \mathrm{~d}$ on average. Taken together, these observations imply a very significant carbon flux via the microbial loop during all seasons in the epilimnion of Lake Kinneret.

Stone et al. (1993), Hadas \& Berman (1998) and Hart et al. (2000) previously suggested that a high proportion of photosynthetically fixed carbon is cycled through the microbial loop in Lake Kinneret. The rapid rates of BBP and high values of BGE reported in this study tend to substantiate this idea and contradict the general perception that the microbial loop plays a less important role in carbon cycling in eutrophic than in oligotrophic aquatic systems.

Although unusual phenomena have been described previously for this lake (e.g. in The New Testament), we doubt that this ecosystem is unique. It would be of considerable interest to know whether the data presented here are characteristic for similar large, warm, mesotrophic-eutrophic lakes.

Acknowledgements. We are grateful to 2 reviewers who helped us to improve the original manuscript considerably. We thank Bina Kaplan and Sara Chava for devoted and excellent technical help and James Easton and Meir Hatab for skillful seamanship. We also thank Ami Nishri and Tamar Zohary for comments, enlightenment and use of unpublished data. This study was supported in part by Grant No. 95-002 from the United States-Israel Binational Foundation, Jerusalem, Israel, and by the Office of the Israel Water Commissioner (Lake Kinneret Ecosystem Modelling Project. Principal Investigators: T. Zohary, J. Imberger). This is a contribution of Israel Oceanographic and Limnological Research.

\section{LITERATURE CITED}

Baines SB, Pace ML (1991) The production of dissolved organic matter by phytoplankton and its importance to bacteria: patterns across marine and freshwater systems. Limnol Oceanogr 36:1078-1090

Berman T (1976) Release of dissolved organic matter by photosynthesizing algae in Lake Kinneret, Israel. Freshw Biol 6:13-18

Berman T, Gerber C (1980) Differential filtration studies of carbon flux from living algae to microheterotrophs, microplankton size distribution and respiration in Lake Kinneret. Microb Ecol 6:189-198

Berman T, Kaplan B (1984) Respiration of Lake Kinneret microplankton measured by carbon loss in the dark. Arch Hydrobiol Beih Ergeb Limnol 19:157-162

Berman T, Pollingher U (1974) Annual and seasonal variations of phytoplankton, chlorophyll and photosynthesis in Lake Kinneret. Limnol Oceanogr 19:31-54

Berman T, Hadas O, Marchaim (1979) Heterotrophic glucose uptake and respiration in Lake Kinneret. Hydrobiologia 62:275-282
Berman T, Stone L, Yacobi YZ, Kaplan B, Schlichter M, Nishri A, Pollingher U (1995) Primary production and phytoplankton in Lake Kinneret: a long-term record (1972-1993). Limnol Oceanogr 40:1064-1076

Berman T, Pollingher U, Zohary T (1998) A short history of stability and change in phytoplankton populations in Lake Kinneret. Isr J Plant Sci 46:73-80

Berman T, Kaplan B, Chava S, Viner Y, Sherr SF, Sherr E (2001) Metabolically active bacteria in Lake Kinneret. Aquat Microb Ecol 23:213-224

Bernard L, Schafer H, Fabien J, Courties C, Muyzer G, Lebaron P (2000) Genetic diversity of total, active and culturable marine bacteria in coastal seawater. Aquat Microb Ecol 23:1-11

Biddanda B, Cotner JB (2002) Love handles in aquatic ecosystems: the role of dissolved organic drawdown, resuspended sediments, and terrigeous inputs in the carbon balance of Lake Michigan. Ecosystems 5:431-445

Biddanda B, Opsahl S, Benner R (1994) Plankton respiration and carbon flux through bacterioplankton on the Louisiana shelf. Limnol Oceanogr 39:1259-1275

Biddanda B, Ogdahl M, Cottner JB (2001) Dominance of bacterial metabolism in oligotrophic relative to euphotic waters. Limnol Oceanogr 46:730-739

Carignan R, Planas D, Vis C (2000) Planktonic production and respiration in oligotrophic shield lakes. Limnol Oceanogr 45:189-199

Chin Leo G, Benner R (1992) Enhanced bacterioplankton production and respiration at intermediate salinities in the Mississippi River plume. Mar Ecol Prog Ser 87:87-103

Choi JW, Sherr EB, Sherr BS (1999) Dead or alive? A large fraction of ETS-inactive marine bacterioplankton cells, as assessed by reduction of CTC, can become ETS-active with incubation and substrate addition. Aquat Microb Ecol 18:105-115

Chrost RJ, Rai H (1994) Microbial enzymatic degradation and utilization of organic matter. In: Oberbeck J, Chrost RJ (eds) Microbial ecology of Lake Plussee. Springer-Verlag, Berlin, p 118-174

Cole JJ (1999) Aquatic microbiology for ecosystem scientists: new and recycled paradigms in ecological microbiology. Ecosystems 2:215-225

Cole JJ, Pace M (1995) Bacterial secondary production in oxic and anoxic freshwaters. Limnol Oceanogr 40:1019-1027

Cole JJ, Findlay S, Pace M (1988) Bacterial production in fresh and saltwater ecosystems: a cross-system overview. Mar Ecol Prog Ser 43:1-10

Cole JJ, Caraco NF, Strayer DI (1989) A detailed organic carbon budget as an ecosystem-level calibration of bacterial respiration in an oligotrophic lake during midsummer. Limnol Oceanogr 34:286-296

Cole JJ, Caraco NF, Peierls BL (1992) Can phytoplankton maintain a positive balance in a turbid, freshwater, tidal estuary? Limnol Oceanogr 37:1608-1617

Cole JJ, Pace ML, Carpenter SR, Kitchell JF (2000) Persistence of net heterotrophy in lakes during nutrient addition and food web manipulations. Limnol Oceanogr 45: $1718-1730$

Cole JJ, Carpenter SR, Kitchell JF, Pace M (2002) Pathways of organic carbon utilization in small lakes: results from a whole-lake ${ }^{13} \mathrm{C}$ addition and coupled model. Limnol Oceanogr 47:1664-1675

Coveney MF, Wetzel RG (1995) Biomass, production and specific growth rate of bacterioplankton and coupling to phytoplankton in an oligotrophic lake. Limnol Oceanogr 40:1187-1200

del Giorgio PA, Cole JJ (1998) Bacterial growth efficiency in 
natural aquatic systems. Annu Rev Ecol Syst 29:503-541 del Giorgio PA, Cole JJ (2000) Bacterial energetics and growth efficiency. In: Kirchman DL (ed) Microbial ecology of the oceans. Wiley-Liss, New York, p 289-325

del Giorgio PA, Duarte CM (2002) Respiration in the open sea. Nature 420:379-384

del Giorgio PA, Peters RH (1994) Patterns in planktonic P:R ratios in lakes. Influence of lake trophy and dissolved organic carbon. Limnol Oceanogr 39:772-787

del Giorgio PA, Cole JJ, Cimbleris A (1997) Respiration rates in bacteria exceed phytoplankton production in unproductive aquatic systems. Nature 385:148-151

Ducklow HW (2000) Bacterial production and biomass in the oceans. In: Kirchman DL (ed) Microbial ecology of the oceans. Wiley-Liss, New York, p 85-120

Ducklow HW, Carlson CA (1992) Oceanic bacterial production. Adv Microb Ecol 12:113-181

Ducklow HW, Kirchman DI, Anderson TR (2002) The magnitude of spring bacterial production in the North Atlantic Ocean. Limnol Oceanogr 47:1684-1693

Fuhrman JA, Azam F (1982) Thymidine incorporation as a measure of heterotrophic bacterioplankton production in marine surface waters: evaluation and field results. Mar Biol 66:109-120

Fukuda R, Ogawa H, Nagata T, Koike I (1998) Direct determination of carbon and nitrogen contents of natural bacterial assemblages in marine environments. Appl Environ Microbiol 64:3352-3358

Geider RJ (1997) Photosynthesis or planktonic respiration? Nature 388:132

Gude H (1990) Bacterial production and the flow of organic matter in Lake Constance. In: Tilzer MM, Serruya C (eds) Large lakes, ecological structure and function. SpringerVerlag, Berlin, p 489-502

Hadas O, Berman T (1998) Seasonal abundance and vertical distribution of Protozoa (flagellates, ciliates), and bacteria in Lake Kinneret, Israel. Aquat Microb Ecol 14:161-170

Hagström $\AA$, Larsson P, Horstedt P, Normark S (1979) Frequency of dividing cells, a new approach to the determination of bacterial growth rates in aquatic environments. Appl Environ Microbiol 37:805-812

Hart DR, Stone L, Berman T (2000) Seasonal dynamics of the Lake Kinneret food web: the importance of the microbial loop. Limnol Oceanogr 45:350-361

Hobbie JE, Crawford CC (1969) Respiration corrections for bacterial uptake of dissolved organic compounds in natural waters. Limnol Oceanogr 14:528-533

Holm-Hansen O, Lorenzen CJ, Holmes RW, Strickland JDH (1965) Fluorometric determination of chlorophyll. J Cons Perm Int Explor Mer 30:3-15

Hopkinson CS, Sherr B, Wiebe WJ (1989) Size-fractionated metabolism of coastal microbial plankton. Mar Ecol Prog Ser 51:155-166

Inkina GA (1985) Some bacteriological parameters of water quality. In: Winberg GG (ed) Ecological system of Naroch Lakes. Belarus University, Minsk, p 223-229

Iriarte A, de Madariaga I, Diez-Garagarza F, Revilla M, Orive E (1996) Primary plankton production, respiration and nitrification in a shallow temperate estuary during summer. J Exp Mar Biol Ecol 208:127-151

Iriberri J, Muela A, Egea L (1985) Heterotrophic bacterial activity in coastal waters: functional relationship of temperature and phytoplankton population. Ecol Model 28:113-120

Jahnke RAD, Craven B (1995) Quantifying the role of heterotrophic bacteria in the carbon cycle: a need for respiration rate measurements. Limnol Oceanogr 40:436-441
Jonas RB, Tuttle JH (1990) Bacterioplankton and organic carbon dynamics in the lower mesohaline Chesapeake Bay. Appl Environ Microbiol 56:747-757

Kirchman DE, K'nees E, Hodson R (1985) Leucine incorporation and its potential as a measure of protein synthesis by bacteria in natural aquatic systems. Appl Environ Microbiol 49:599-607

Kristiansen K, Nielsen H, Riemann B, Fuhrman JA (1992) Growth efficiencies of freshwater bacterioplankton. Microb Ecol 24:145-160

Lee S, Fuhrman JA (1987) Relationships between biovolume and biomass of naturally-derived marine bacterioplankton. Appl Environ Microbiol 53:1298-1303

Luz B, Barkan E, Sagi Y, Yacobi YZ (2002) Evaluation of community respiratory mechanisms with oxygen isotopes: a case study in Lake Kinneret. Limnol Oceanogr 47:33-42

Marra J (2002) Approaches to the measurement of plankton production. In: Williams PJLeB, Thomas DN, Reynolds CS (eds) Phytoplankton productivity: carbon assimilation in marine and freshwater ecosystems. Blackwell Science, Oxford, p 78-108

Moran XAG, Gasol JM, Pedros-Alio C, Estrada M (2001) Dissolved and particulate primary production and bacterial production in offshore Antarctic waters during austral summer: coupled or uncoupled? Mar Ecol Prog Ser 222: 25-39

Nishri A, Zohary T, Gophen M, Wynne D (1998) Lake Kinneret dissolved oxygen regime reflects long term changes in ecosystem functioning. Biogeochemistry 42:253-283

Ostapenya AP (1971) Biological oxygen consumption. In: Khailov KM (ed) Functioning of pelagic communities in the tropical areas of the ocean. Nauka, Moscow, p 250-254

Pace M, Cole JJ (1994) Primary and bacterial production in lakes: are they coupled over depth? J Plankton Res 16: 661-672

Packard TT (1971) The measurements of respiratory electrontransport activity in marine phytoplankton. J Mar Res 29: 235-244

Parparov A, Berman T, Grossart HP, Simon M (1998) Metabolic activity associated with lacustrine seston. Aquat Microb Ecol 15:77-87

Pinhassi J, Berman T (2003) Differential growth response of colony-forming $\alpha$ - and $\gamma$ - proteobacteria in dilution culture and nutrient addition experiments from Lake Kinneret (Israel), the Eastern Mediterranean Sea, and the Gulf of Eilat. Appl Environ Microbiol 69:199-211

Porter KG, Feig YS (1980) The use of DAPI for identifying and counting aquatic microflora. Limnol Oceanogr 25:943-948

Riemann B, Søndergaard M (1986) Regulation of bacterial secondary production in two eutrophic lakes and in experimental enclosures. J Plankton Res 8:519-536

Rivkin RB, Legendre L (2001) Biogenic carbon cycling in the upper ocean: effects of microbial respiration. Science 291: 2398-2400

Robinson C, Serret P, Tilstone G, Teira E, Zubkov MV, Rees AP, Malcolm E, Woodward S (2002) Plankton respiration in the Eastern Atlantic Ocean. Deep-Sea Res 49:787-813

Roland F, Cole JJ (1999) Regulation of bacterial growth efficiency in a large turbid estuary. Aquat Microb Ecol 20: 31-38

Scavia D (1988) On the role of bacteria in secondary production. Limnol Oceanogr 33:1220-1224

Scavia D, Laird GA (1987) Bacterioplankton in Lake Michigan: dynamics, controls and significance to carbon flux. Limnol Oceanogr 32:1017-1033

Schwaerter S, Søndergaard M, Riemann B, Moller-Jensen I 
(1988) Respiration in eutrophic lakes: the contribution of bacterioplankton and bacterial growth yield. J Plankton Res 10:515-531

Serruya C, Gophen M, Pollingher U (1980) Lake Kinneret carbon flow patterns and ecosystems management. Arch Hydrobiol 88:265-302.

Sherry ND, Boyd PW, Sugimoto K, Harrison PJ (1999) Seasonal and spatial patterns of heterotrophic bacterial production, respiration, and biomass in the subarctic NE Pacific. Deep-Sea Res 46:2557-2578

Shiah FK, Ducklow HW (1994) Temperature regulation of heterotrophic bacterioplankton abndance, production, and specific growth rate in Chesapeake Bay. Limnol Oceanogr 39:1243-1258

Simon M, Azam F (1989) Protein content and protein synthesis rates of planktonic marine bacteria. Mar Ecol Prog Ser 51:201-212

Simon M, Tilzer MM, Müller H (1998) Bacterioplankton dynamics in a large mesotrophic lake. 1. Abundance production and growth control. Arch Hydrobiol 143:385-407

Smith EM, Kemp EM (2003) Planktonic and bacterial respiration along and estuarine gradient: responses to carbon and nutrient enrichment. Aquat Microb Ecol 30:251-261

Smith S, Azam F (1993) A simple economical method for measuring bacterial protein synthesis rates using ${ }^{3} \mathrm{H}$ leucine. Mar Microb Food Webs 6:107-114

Søndergaard M, Danielsen M (2001) Active bacteria (CTC+) in temperate lakes: temporal and cross-system variations. J Plankton Res 23:1195-1206

Søndergaard M, Middelboe M (1995) A cross-system analysis of labile dissolved organic carbon. Mar Ecol Prog Ser 118: 283-294.

Søndergaard M, Hansen B, Markager S (1995) Dynamics of dissolved organic carbon lability in an eutrophic lake. Limnol Oceanogr 40:46-54

Søndergaard M, Borch NH, Riemann B (2000) Dynamics of biodegradable DOC produced by freshwater plankton communities. Aquat Microb Ecol 23:73-83

Steemann-Nielsen E (1952) The use of radioactive carbon $\left({ }^{14} \mathrm{C}\right)$ for measuring organic production in the sea. J Cons Perm Int Explor Mer 18:117-140

Stone L, Berman T, Bonner R, Barry S, Weeks SW (1993) Lake

Editorial responsibility: Karel Šimek,

České Budějovice, Czech Republic
Kinneret: a seasonal model for carbon flux through the planktonic biota. Limnol Oceanogr 38:1680-1695

Strayer D (1988) On the limits to secondary production. Limnol Oceanogr 33:1217-1220

Toolan T (2001) Coulometric carbon-based respiration rates and estimates of bacterioplankton growth efficiencies in Massachusetts Bay. Limnol Oceanogr 46:1298-1308

Torreton JP, Pages J, Talbot V (2002) Relationships between bacterioplankton and phytoplankton biomass, production and turnover rate in Tuamotu atoll lagoons. Aquat Microb Ecol 28:267-277.

Troncoso VA, Daneri G, Cuevas LA, Jacob B, Montero P. (2003) Bacterial carbon flow in the Humbold Current System off Chile. Mar Ecol Prog Ser 250:1-12

Tuomi P (1997) Bacterial carbon production in the northern Baltic: a comparison of thymidine incorporation and FDC based methods. Mar Ecol Prog Ser 153:59-66

Van Wambeke F, Christaki U, Bianchi M, Psatrra S, Tselepides A (2000) Heterotrophic bacterial production in the Cretan Sea (NE Mediterranean). Prog Oceanogr 46: 205-216

White PA, Kalff J, Rasmussen JB, Gasol JM (1991) The effect of temperature and algal biomass on bacterial production and specific growth rate in freshwater and marine habitats. Microb Ecol 21:99-118

Williams PJLeB (1970) Heterotrophic utilization of dissolved organic compounds in the sea. I. Size distribution of population and relationship between respiration and incorporation of growth substrates. J Mar Biol Assoc UK 50: $859-870$

Williams PJLeB (1981) Microbial contribution to overall marine plankton metabolism: direct measurements of respiration. Oceanol Acta 4:359-364

Williams PJLeB (1998) The balance of plankton respiration and photosynthesis in the open oceans. Nature 394: $5557-5560$

Williams PJLeB, Thomas DN, Reynolds CS (2002) Phytoplankton productivity: carbon assimilation in marine and freshwater ecosystems. Blackwell Science, Oxford

Winberg GG (1971) Some results of studies of lake productivity in the Soviet Union within the International Hydrobiological Programme. Hydrobiol J 7:5-17

Submitted: June 10, 2003; Accepted: September 18, 2003 Proofs received from author(s): January 7, 2004 